\title{
Heating and cooling a building using water from boreholes
}

\author{
M. R. Duque ${ }^{1}$, J. Pascoal ${ }^{1}$ \\ ${ }^{1}$ Department of Physics, University of Evora \\ Rua Romão Ramalho 59, 7000-671, Évora (Portugal) \\ Phone:00351 266745372 ;Fax:351 266745394 ; e-mail: mrad@uevora.pt,
}

\begin{abstract}
The work which is presented is part of a more extensive study related to a system of heating and cooling an old building of the 16th century, of the Evora University using water retired from four boreholes located in the vicinity of the building. In this work we present only the model made for heating and for cooling a room, the amount of water needed, and the maximum number of rooms which could be heated or cooled with the water available. The second part of the work is related with the time needed for the hole return its temperature, after being introduced in it water coming from the building. We conclude that the maximum number of rooms which can be cooled is different from the number of rooms that can be warmed. We also conclude that the introduction of water in the holes will affect only a small area around the holes, and the perturbation of the temperature occurs in a short period of time.
\end{abstract}

\section{Key words}

Heating, cooling, water, geothermal energy, heat pumps

\section{Introduction}

When we look to the direct use of geothermal fluids actually made, we see that the use of geothermal heat pumps is near $67 \%$ of all uses. This is due to the fact that they can be installed everywhere and have a low cost of operation. The system we studied uses a heat pump to heat the water that comes from the holes after sending it to the building. The returning water is sent again to one of the holes. The temperature of the water in the hole studied was $19^{\circ} \mathrm{C}$. We show that it is possible to use this water to cool or warm the building without prior heating.

\section{The climate of Évora}

The city of Evora and the Alentejo interior have a very special climate. In summer it is very hot and dry, reaching extremes of temperature. In the coldest season (autumn and winter) occurs heavy precipitation with the possibility of flooding.

The city of Evora has a particular climate with average temperatures of $5^{\circ} \mathrm{C}$ in January and $35^{\circ} \mathrm{C}$ in August. The aquifers are very dependent on rainwater and evaporation but recover your levels each year in winter. The average annual precipitation in the city is around $650 \mathrm{~mm}$. In July 2013 the average minimum temperature was $12.8^{\circ} \mathrm{C}$ and the average maximum temperature was $29,5^{\circ} \mathrm{C}$ [1]. The temperature measured in the water of the hole, at 30 meters depth was $19^{\circ} \mathrm{C}$ from January to September 2013 .

\section{Main properties of the building}

The climatization system studied is installed in one old building of the Évora University named Colégio do Espírito Santo. It is a sixteenth century building known for their cloisters and the baroque facade of the Sala dos Atos. Its walls are partially covered by tiles of the seventeenth century. The building has the characteristics of the construction of their time (sixteenth century). It is a robust building with very thick walls composed of clay materials, and has a large thermal inertia. The building was built for a University and has many classrooms and rooms for administration offices. We made the study for one room and considered all the rooms with the same dimensions. The room measured has a width of $6.72 \mathrm{~m}$ and $10.19 \mathrm{~m}$ long and the thickness of the walls is $0.705 \mathrm{~m}$. The door has dimensions of $2.42 \mathrm{~m} \times 1.46 \mathrm{~m}$. The thickness of the door is $0.05 \mathrm{~m}$. The room has two windows with dimensions of $1.33 \mathrm{~m} \times 1.46 \mathrm{~m}$ and a thickness of $0.05 \mathrm{~m}$.

In order to weatherize the rooms, fan coil units were installed near the ceilings. The choice of this location is due to the fact that the tiles on the walls are from the seventeenth century and can not be removed like the floor.

\section{The model}

This model was developed to study the energy needs for climatization the rooms of the Colégio do Espírito Santo, as well as the capacity of the energy source used. We made models for summer and winter and compared the results obtained.

Two different situations were considered: One for winter, with a temperature of $22^{\circ} \mathrm{C}$ inside the room and an external temperature of $10^{\circ} \mathrm{C}$.In the other, for summer, we used a temperature of $24^{\circ} \mathrm{C}$ inside the room and an external temperature of $30^{\circ} \mathrm{C}$. For the thermal conductivity of the material of the walls a value of $1.4 \mathrm{WK}^{-1} \mathrm{~m}^{-1}$ was used. The rooms looses/receives heat by conduction and by convection. In the calculation of the heat lost/received by convection a wind velocity of $1 \mathrm{~ms}^{-1}$ was used. Several situations were modelled with door and windows closed, 
door open and windows closed, door closed and windows open and door and windows open. In all the situations, the water needed to heat the room was calculated using [2]

$$
\mathrm{F}_{\mathrm{in}}=\mathrm{Q}_{\mathrm{L}} /\left[\mathrm{C}_{\mathrm{p}}\left(\mathrm{T}_{\mathrm{G}}-\mathrm{T}_{\mathrm{p}}\right)\right]
$$

The values used are $4180 \mathrm{~J} \mathrm{Kg}^{-1} \mathrm{~K}^{-1}$ for the $\mathrm{C}_{\mathrm{P}}$ of the water and $\mathrm{T}_{\mathrm{p}}=17^{\circ} \mathrm{C}, \mathrm{T}_{\mathrm{G}}=12^{\circ} \mathrm{C}$, for winter and $\mathrm{T}_{\mathrm{P}}=24^{\circ} \mathrm{C}, \mathrm{T}_{\mathrm{G}}=19^{\circ} \mathrm{C}$ for summer [3]. The results obtained for winter are summarised on Table I.

Table I - Results obtained for winter

\begin{tabular}{|l|c|c|}
\hline SITUATION & $\mathrm{Q}_{\mathrm{CONV}}(\mathrm{J} / \mathrm{S})$ & $\mathrm{F}_{\mathrm{IN}}(\mathrm{L} / \mathrm{H})$ \\
\hline Door open + windows open & 196 & 624 \\
\hline Door open+ windows closed & 107 & 608 \\
\hline Door closed+ windows open & 90 & 606 \\
\hline Door close+1window open & 45 & 598 \\
\hline Door open+1 window open & 151 & 616 \\
\hline Door closed+windows close & 0 & 590 \\
\hline
\end{tabular}

The amount of heat lost by conduction for this room is $3425 \mathrm{Js}^{-1}$.

In the model done to heat the room, were considered three different situations:

A-The water goes directly from the holes to a heat exchanger located in the room to be heated.

$\mathrm{B}-\mathrm{The}$ water goes from the hole to a heat exchanger and heats a circulating fluid refrigerant with low boiling point. This fluid goes to the compressor and to another heat exchanger that exchanges heat with the air located in the room.

C-The water goes directly from the hole to the compressor and to the heat exchanger that exchanges heat with the air in the room.

The amount of water used in all the situations was $1.33 \mathrm{Ls}$ 1 . We reached this value by making the calculations according to the existing flow in four holes. If we consider the situation door open + windows open, using water from the four holes, the system can warms 34 rooms Considering that we have a system with 3 holes for water catchment and the other be simply for the reception of water from the building we have a possible climatization in 33 rooms.. The results obtained for the energy that is necessary to remove from the room in summer are shown on Table II.

Table II - Results obtained for summer

\begin{tabular}{|l|c|c|}
\hline \multicolumn{1}{|c|}{ SITUATION } & $\mathrm{Q}_{\mathrm{CONV}}(\mathrm{J} / \mathrm{S})$ & $\mathrm{F}_{\mathrm{IN}}(\mathrm{L} / \mathrm{H})$ \\
\hline Door open + windows open & 65.5 & 306 \\
\hline Door open + windows closed & 35.5 & 301 \\
\hline Door closed + windows open & 30.0 & 300 \\
\hline Door close+1 window open & 15.0 & 298 \\
\hline Door open +1 window open & 50.5 & 304 \\
\hline Door closed + windows close & 0 & 295 \\
\hline
\end{tabular}

Comparing the results obtained for summer and for winter we can see that the energetic needs and the amount of water required for air conditioning in summer are lower than in winter. This finding is contrary to that achieved in most systems. This is due to the large thermal inertia of the building, with very thick walls, and to the materials used in its construction.

The situations $\mathrm{A}, \mathrm{B}$ and $\mathrm{C}$ were considered for summer. The results obtained shows that, with the four holes, it is possible to refrigerate 69 rooms identical to that used in the study. Using only water from three holes it is possible to acclimate 66 classrooms instead 69 . The hole that we withdrew from the climatization system is RA4 and has a maximum capacity of water supply of $600 \mathrm{~L} / \mathrm{h}$.

\section{The temperature in the hole that receives the returning water}

In fact, the results obtained with the described model can not be fully achieved because we will need to have a hole to receive the water from the building. Records obtained in the hole show that the water temperature rises during the time interval in which water is being introduced in the hole. We can see, in Figure 1 the temperature of the water in the hole without perturbations and two intervals with perturbations recorded in the hole.

The curve shows that the temperature variation over time is characteristic of heat transfer by conduction. The temperature of the water in the hole depends on the amount of water at $19^{\circ} \mathrm{C}$, thermal conductivity and heat capacity of the existing rock in the region of the holes (gneiss) [4].
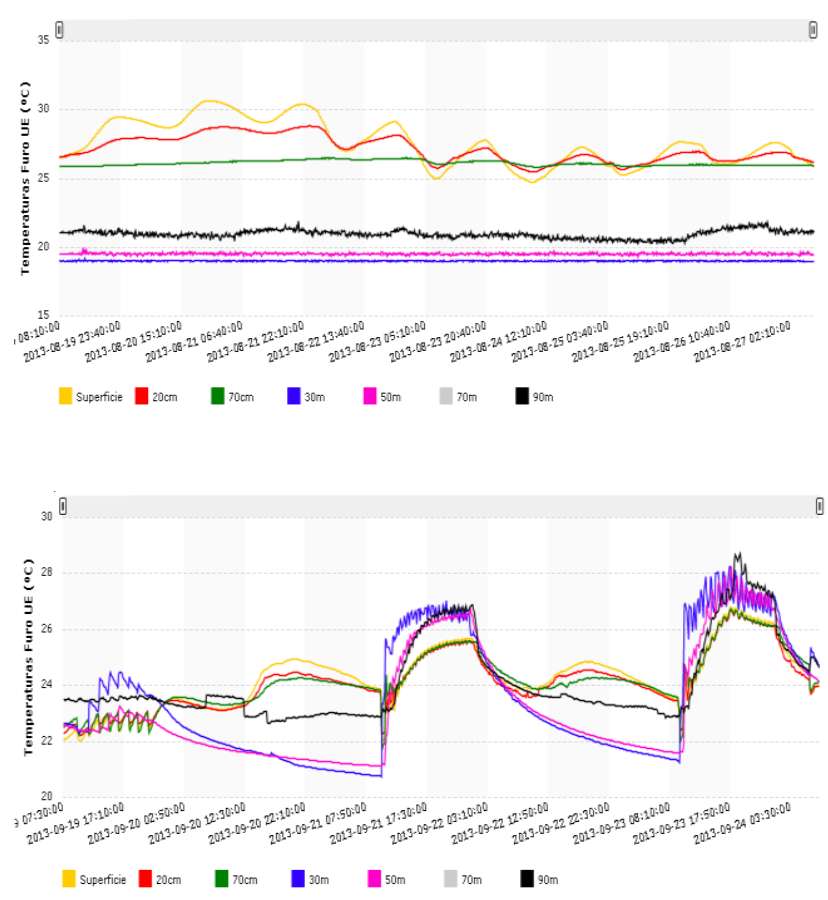

Fig 1. Temperature values recorded in Borehole RA4.

I- Temperatures without perturbations, II- Two intervals of perturbation

The temperature perturbations recorded in the water of the borehole RA-4 began on September 14 at 6 hours and 50 minutes and apparently finished on October 12 at 0 hours and 10 minutes. The temperatures returned to its usual values (about $20^{\circ} \mathrm{C}$ ) on October 15 at 4 hours and 10 minutes. The perturbations of temperature studied in this work began on September 14 at 11 hours and 10 minutes. The first maximum value was recorded on September 14, 
having the water temperature a value of $28^{\circ} \mathrm{C}$ which was maintained until September 15 at 01 hour and 10 minutes. On September 16, at 6 hours and 40 minutes, the temperature of the water was $23{ }^{\circ} \mathrm{C}$, and a value of $27^{\circ} \mathrm{C}$ was recorded again on September 16, at 09 hours and 10 minutes. We think that these perturbations are associated with water entering in the borehole. If we compare these figures of the temperature of the water introduced in the hole with the values obtained from the models we present, we can easily conclude that they are much higher than the values we obtained. This fact represents excess energy used to heat the water, making the process more expensive. The payback period of the temperature to normal values was about $33 \mathrm{~h}$. The normal levels of the temperature were registered on September 23, at 9hours and 40 minutes.

Using the time range in which hot water was introduced into the hole $(33 \mathrm{~h}=118800 \mathrm{~s})$ and a thermal capacity of the water of $4186 \mathrm{~J} / \mathrm{kg} . \mathrm{K}$ we can conclude that the heat introduced into the hole was $284 \times 10^{6} \mathrm{~J}$. In this calculation was used the maximum flow rate $(5,94 \mathrm{~L} / \mathrm{s})$. Utilizing for the gneiss thermal capacity a value of $200 \mathrm{~J} \cdot \mathrm{kg}^{-1} \cdot \mathrm{K}^{-1}$ and considering that all the heat lost by the water will be supplied to the rock adjacent we can conclude that only $47333 \mathrm{~kg}$ of the rock received energy in the time interval considered. If we consider a value of $2,6 \times 10^{3} \mathrm{~kg} \cdot \mathrm{m}^{-3}$ for the gneiss density we reach a volume of $18,2 \mathrm{~m}^{3}$. This means that the introduction of water into the hole will only affect the temperature of the soil near the surroundings of the existing hole. On the other hand, if we consider the amount of water introduced into the hole and the value obtained for the aquifer hydraulic transmissivity ( $\left.0.30 \mathrm{~m}^{2} / \mathrm{day}\right)[5]$ and the period of time where it was verified a drop in temperature, we conclude that the result obtained by calculations is in agreement with this value.

A dipole-dipole electrical profile was done to check the connection of the water into the holes of the system [6]. To carry out this study 32 current injection electrodes were installed, with $5 \mathrm{~m}$ distance between themselves. The electrical tomography was performed on the exterior side of the wall of the sports grounds in Colégio do Espírito Santo, with a total length of $155 \mathrm{~m}$.

Considering that places with lower electrical resistivity are possibly areas filled with water, it is noted that there are some possible water bags. The electrical resistivity model made to interpret the results obtained with the dipole-dipole profile performed close to hole RA4 shows that the aquifer can be isolated from other aquifers located in the region. We must say however that the profile does not pass through the hole being away about a distance of 10 meters.

The amount of water that can enter in the hole indicates the possible existence of small unfilled faults in the region (lithological logs indicate several fracture zones traversed by the hole). The temperatures recorded in the hole from January to September 2013 have remained constant showing the non existence of hydraulic connection with the surface.

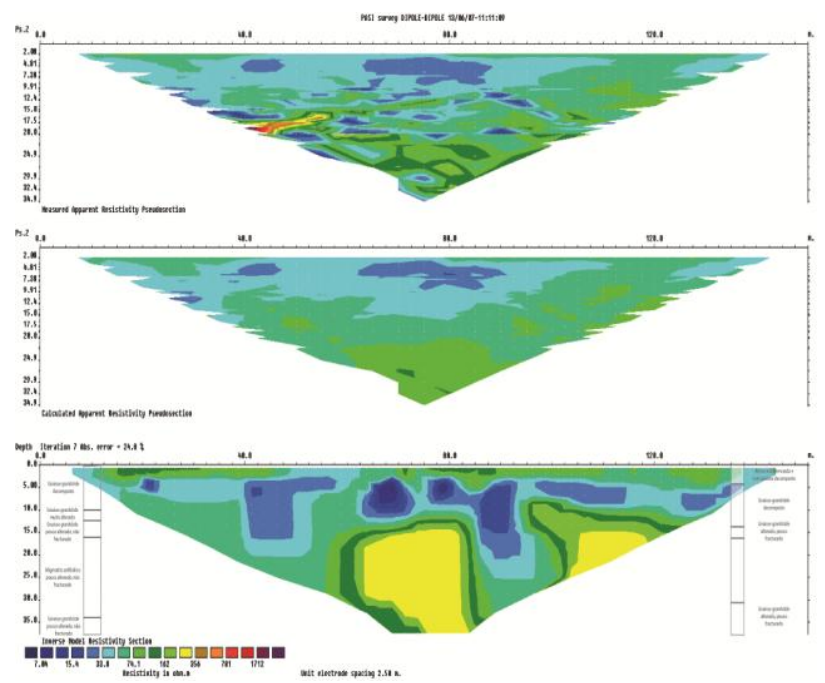

Fig 2. Electrical resistivity model.

The time necessary to attain an equilibrium temperature and the temperature value reached allow us to draw conclusions about the quantity of available water in the aquifer before the introduction of hot water.

\section{Discussion and conclusions}

This work tries to show that to use correctly a system like one described it is necessary to make previous studies about climate, temperatures on the soil, models to infer the energy needs and the correctly way to work with the systems projected. In the case studied we conclude that the amount of energy used to heat the water is larger than the value required to obtain the objectives required. Although the hot water inserted into the hole affect a small area and therefore does not have consequences for thermal soil contamination and adjacent aquifers, this hot water represents an additional expense.

An important fact associated with the characteristics of the building is that the amount of water required to make the climatization in the summer is lower than that necessary to use in winter. This conclusion is contrary to that found in modern buildings where it is more difficult to make the climatization than in the winter. From this study it can be affirmed that a system of direct use would be more appropriate for this situation because of the temperature existing in the holes and once the system is located in a temperate climate region, without great extremes of temperature.

We can conclude from the electric profile performed, that the introduction of hot water in hole RA4 will not affect the temperature of the soil in the studied area.

The fact that the thermal conductivity of the rock be about seven times higher than the thermal conductivity of the water [7] allows the conclusion that the heat transfer in the rock is faster and temperature gradients with low values. These facts are in agreement with the conclusions presented.

\section{Acknowledgment}

We want to thank to CGE and Prof. Rui Salgado that allowed the use of temperature data obtained in the soil in 
two places nearby Évora. Acknowledgements are also due to Eng. José Pombinho, Sérgio Aranha, Josué Figueira and Eng. Peixeiro Ramos. We had the kelp of all of them. Finally a special thanks to Samuel Bárias for his work in the calibration of the probes, installation in the borehole, collection and processing of data and introduction in a database

\section{REFERENCES}

[1]Boletim Climatológico mensal-Portugal Continental .Publicações IPMA, Lisboa (2013)

[2]W.E. Glassley, Geothermal Energy. Renewable Energy and the Environment, CRC Press, London (2010),pp.183-223.

[3] Pascoal, J., Reservatórios Geotérmicos: Estudo de um Caso Real, Universidade de Évora, Évora, (2013).

[4]Azenha, R. L.," Relatório Final de execução dos Furos da Universidade de Évora - Colégio do Espírito Santo",Internal report2009, Évora.

[5]Montes, V:Captação de águas subterráneas para aproveitamento geotérmico -caso de estudo do Colégio do Espírito Santo,Universidade de Évora, Internal Report (2009)

[6]Duque, M., Pascoal, J., "An attempt to increase the performance of a climatizing system using water from boreholes, in an old building", European Geothermal Congress 2013 (EGC 2013), Pisa, Italy

[7] Clark and Niblett,"Terrestrial Heat Flow in the Swiss Alps", Monthly Notices of the Royal Astronomical Society Geophysical Supplement1956, v.7, pages 176-195. 